\title{
Stem cell - based gene therapy
}

\author{
Z. Nazir, S. Irshad \\ Institute of Biochemistry and Biotechnology \\ Punjab University, Lahore, Pakistan \\ saba.ibb@pu.edu.pk
}

\begin{abstract}
Stem cells have huge potential for regenerative medicine. Adult stem cell (HSC)-based therapies have been proved to be safe and efficient for several decades, and adult MSC therapies are showing efficacy in some experiments while in other trials mixed results are obtained such as only short lived effects due to poor cellular retention or other reasons that have to be further tested. Although iPSCs might suggest a great hope for the stem cell therapy, still there are important safety issues to be considered before these cells are marketed for clinical trials. However, the advanced potential to generate stem cell lines, matched to a particular patient, and to perform homologous gene correction or targeted transgene insertion into a safe dock site in the genome prior to further expansion and differentiation offer great prospects for future regenerative medicine. Furthermore, the development of the recombinant adeno-associated virus (rAAV) technology and the use of the Zinc Finger Nuclease (ZFN) technology are promoting the homologous recombination as a best possible tool for stem cell-based gene therapy.
\end{abstract}

Keywords: Adult stem cells, MSCs, iPSCs, ZFN, rAAV, homologous gene correction, regenerative medicine.

Introduction. Stem cell gene therapy is a novel therapeutic branch of modern medicine. Gene therapy is still highly experimental, but has the potential to become an important course of therapy. In principle, it allows the transfer of genetic information into patient tissues and organs. Subsequently, the diseased genes can be eradicated or their normal functions restored. Moreover, the procedure ensures the addition of novel functions to cells, such as the production of immune system mediator proteins that facilitate to fight cancer and other diseases.

In the beginning, monogenic inherited diseases, such as cystic fibrosis, were considered prime targets for gene therapy. For example, in the pioneering study on the correction of adenosine deaminase deficiency, a lymphocyte associated severe combined immunodeficiency (SCID), was attempted for gene therapy trial [1], although no modification of immune function was observed. The first successful gene therapy clinical trial for a monogenic disorder is related to another type of SCID, caused by mutation of the X chromosome-linked lymphocyte growth factor receptor [2].

(c) Institute of Molecular Biology and Genetics, NAS of Ukraine, 2013
While the positive therapeutic outcome was celebrated as a step forward for gene therapy, a serious negative aspect became evident subsequently. By February 2005 , three children out of seventeen, who had been successfully treated for X linked SCID, developed leukemia because the vector inserted near an oncogene unintentionally caused its expression in the genetically-engineered lymphocyte target cells [3]. On a more positive note, a small number of patients with adenosine deaminase deficient SCID have been successfully treated by gene therapy without any adverse side effects [4].

Another emerging approach to treat disorders requiring the replacement of injured or dying cells is to substitute those cells with healthy ones generated from stem cells, which have the potential to differentiate into multiple mature cell types. Recent discoveries, based on embryonic stem cells (ESCs) and induced pluripotent stem cells (iPSCs), elevate the hope for future regenerative medicine application, with one human ESC-based therapy already being tested in a first-in-man phase I clinical trial. In spite of the great potential, there are technical challenges to be overcome before pscs can be applied to clinical practice in a broader mode. 
Progression of gene therapy. Gene therapy can be performed either by direct transfer of genes into the patient or by using living cells as vehicles to transport the genes of interest. Both modes have certain advantages and disadvantages. Direct gene transfer is particularly attractive because of its relative simplicity. In this case, genes are delivered directly into a patient's tissues or bloodstream by packaging into liposomes or other biological microparticles. Alternately, the genes are packaged into genetically engineered viruses, such as retroviruses or adenoviruses. Due to biosafety issues, the viruses are usually transformed so that they are not toxic or infectious, meaning they are replication incompetent. These basic tools of gene therapists have been widely optimized over the past 10 years.

In many cases, direct gene transfer does not allow very fine control over the therapeutic gene. This is because the transferred gene either accidentally integrates into the patient's chromosomes or persists unintegrated for a pretty short period of time in the targeted tissue. Moreover, the targeted organ or tissue is not always easily available for direct application of the therapeutic gene.

On the other hand, the therapeutic genes can be delivered using living cells. This procedure is relatively complex in comparison to direct gene transfer, and can be divided into three major steps. In the first step, cells from the patient or other sources are isolated and propagated in the laboratory. Second, the therapeutic gene is introduced into these cells, applying methods similar to those used in direct gene transfer. Ultimately, the genetically modified cells are returned to the patient.

The use of cells as gene transfer vehicles has certain advantages. In the laboratory dish, cells can be manipulated much more precisely than in the body. Some of the cell types that continue to divide under laboratory conditions may be expanded significantly before reintroduction into the patient.

Moreover, some cell types are able to localize in particular regions of the human body, such as hematopoietic stem cells, which return to the bone marrow. This «homing» phenomenon may be useful for applying the therapeutic gene with regional specificity. A major disadvantage, however, is the additional biological complexity brought into systems by living cells. Isolation of a specific cell type requires not only extensive knowledge of biological markers, but also insight into the requirements for that cell type to stay alive in vitro and continue to divide.

Importance of stem cells for gene therapy. Stem cells can be classified as embryonic or adult, depending on their origin. The role of adult stem cells is to maintain an established collection of mature cell types in essentially steady state number over the life span of an organism. Although adult tissues with a high turnover rate, such as blood, skin, and intestinal epithelium, are maintained by the tissue specific stem cells, stem cells themselves rarely divide. However, in certain situations, such as during tissue repair after injury or following transplantation, stem cells division may become more frequent. The prototypic example of adult stem cells, the hematopoietic stem cell, has already been demonstrated to be of utility in gene therapy $[2,4]$. Although they are relatively rare in the human body, these cells can be readily isolated from bone marrow or after mobilization into peripheral blood. Specific surface markers allow the identification and enrichment of the hematopoietic stem cells from a mixed population of bone marrow or peripheral blood cells.

After in vitro manipulation, these cells may be retransplanted into patients by injection into the bloodstream, where they travel automatically to the place in the bone marrow in which they are functionally active. Hematopoietic stem cells that have been explanted, in vitro manipulated, and retransplanted into the same patient (autologous transplantation) or a different patient (allogeneic transplantation) retain the ability to contribute to all mature blood cell types of the recipient for an extended period of time. Another type of adult bone marrow-derived stem cells with potential use as a vehicle for gene transfer is the mesenchymal stem cell, which has the ability to form cartilage, bone, adipose (fat) tissue, and marrow stroma [5]. Recently, a related stem cell type, the multipotent adult progenitor cell, has been isolated from bone marrow that can differentiate into multiple lineages, including neurons, hepatocytes, endothelial cells and other cell types [6]. Other adult stem cells have been identified, such as those in the central nervous system and heart, but these are less well characterized and not as easily accessible [7].

The traditional method to introduce a therapeutic gene into hematopoietic stem cells from bone marrow or peripheral blood involves the use of a vector derived from a certain class of viruses, called a retrovirus. One 
type of retroviral vector was initially employed to show proof of principle that a foreign gene introduced into bone marrow cells may be stably maintained for several months [8]. However, these particular retroviral vectors were only capable of transferring the therapeutic gene into actively dividing cells. Since most adult stem cells divide at a relatively slow rate, efficiency was rather low. The vectors derived from other types of retroviruses (lentiviruses) and adenoviruses have the potential to overcome this limitation, since they target non dividing cells as well.

The major drawback of these methods is that the therapeutic gene frequently integrates more or less randomly into chromosomes of the target cell. In principle, this is dangerous, because the gene therapy vector can potentially modify the activity of neighboring genes either positively or negatively in close proximity to the insertion site or even inactivate host genes by integrating into them. These phenomena are referred to as «insertional mutagenesis». In extreme cases, such as in the X-linked SCID gene therapy trials, these mutations contribute to the malignant transformation of the targeted cells, ultimately resulting in cancer.

Another major limitation of using adult stem cells is that it is relatively difficult to maintain the stem cell state during ex vivo manipulations. Under current suboptimal conditions, adult stem cells tend to lose their stem cell properties and become more specialized, giving rise to mature cell types through a process termed «differentiation». Recent advances in supportive culture conditions for mouse hematopoietic stem cells may ultimately facilitate more effective use of human hematopoietic stem cells in gene therapy applications $[9,10]$.

Embryonic stem cells and ethical concerns. Embryonic stem cells are capable of unlimited self renewal while maintaining the potential to differentiate into derivatives of all three germ layers. Even after months and years of growth in the laboratory, they retain the ability to form any cell type in the body. These properties reflect their origin from cells of the early embryo at a stage during which the cellular machinery is geared toward the rapid expansion and diversification of cell types. The murine embryonic stem cells were isolated over 25 years ago and paved the way for the isolation of nonhuman primate, and finally the human embryonic stem cells [11-13].
Experiments performed with the human embryonic stem cells in the last few years indicate that these cells have the potential to make an important impact on medical science, at least in certain fields. Embryonic stem cells are, no doubt, the ultimate solution for the successful gene therapy but religious scholars of the whole world have posed serious ethical concerns on the use of embryonic stem cell. So, in most parts of the world the use of embryonic stem cells for research purposes have been banned.

Gene targeting in human somatic cells by homologous recombination. It is extremely useful to be able to do gene targeting by homologous recombination in human somatic cells. In the last few years, two different strategies have been developed to increase the rate of gene targeting in human somatic cells: the use of recombinant adeno-associated virus and the stimulation of gene targeting by DNA double-strand breaks.

Homologous recombination by recombinant adenoassociated virus (rAAV). The first indication that gene targeting in mammalian somatic cells might be possible at frequencies that could be experimentally useful came from the work of David Russell and his colleagues who used rAAV [14]. rAAV is a single-stranded DNA virus of the parvovirus family that depends on cells being co-infected with either adenovirus or herpes virus to be replicated. The normal nucleic acid structure of AAV consists of the Rep and Cap genes flanked by inverted terminal repeats (ITR's).

In rAAV, the Rep and Cap genes are replaced with an expression cassette including a promoter and a gene of interest. The recombinant virus is then made in HEK-293 cells by providing the Rep and Cap protein products in trans. rAAV is capable of infecting a variety of cell types and has been studied as a possible vector for many gene therapy trials, including treatment for hemophilia B $[15,16]$. Once rAAV infects cells it can be maintained episomally in non-dividing cells or can integrate randomly into the genome, just like other fragments of DNA. Russell and his colleagues found, however, that rAAV integrated via homologous recombination at a much higher frequency than anticipated [14]. The rate of gene targeting by homologous recombination was directly related to the multiplicity of infection; that is, the more viruses infected cells, the higher the rate of gene targeting. Under certain circumstances, 
rAAV can achieve gene targeting rates of $1 \%$ or greater. The mechanism by which rAAV causes a high rate of gene targeting is a mystery.

Nonetheless, gene targeting by rAAV continues to be developed as a technology, and a protocol to streamline the production of rAAV virus for gene targeting has been established [17]. There are good reasons to expect that this technology could be broadly useful for mammalian geneticists.

Homologous recombination induced by DNA double-strand breaks (DSBs). The second way to stimulate ge ne targeting in mammalian somatic cells is to create DNA DSBs in the genomic target. Homologous recombination is an evolutionarily conserved mechanism to repair DSBs.

In the normal repair of DSBs by homologous recombination, the sister-chromatid, an exact duplicate of the damaged DNA, serves as the template for homologous recombination. In this way, homologous recombination is considered the most accurate form of DSB repair. If the DSB was repaired by homologous DNA that was not the sister-chromatid, such as an extra-chromosomal fragment of DNA, it might be possible to «trick» the cell into undergoing gene targeting. In the mid-1990's several groups explored this possibility by using the I-SceI endonuclease (Sce), which is a yeast homing endonuclease $[18,19]$. Sce differs from standard restriction endonucleases (which have recognition sites of 4, 6, or 8 basepairs) by having a recognition site of 18 basepairs. Due to the long recognition site homing endonucleases are sometimes referred to as «meganucleases». When Sce is expressed in a vertebrate cell that has a Sce recognition site (Sce site) integrated into its genome, Sce will create a DSB at its recognition site [20]. That is, Sce is active in genomic DNA with its accompanying chromatin modifications in vertebrate cells. If Sce could create a DSB in the genome, then could that DSB serve as a stimulus for gene targeting by homologous recombination?

To satisfy this question, Sce sites were inserted into mutated reporter genes that were then integrated into the genome of different mammalian cells. A plasmid that expressed Sce and a plasmid that could serve as a repair template were then introduced into these cells. If homologous recombination occurred between the repair template and the mutated integrated reporter gene, then the reporter gene would become functional. The frequency of such spontaneous gene targeting is approximately one in a million. The limitation, of course, to this system, is that the Sce site has to be introduced into the desired target gene beforehand. Since no mammalian gene has the endogenous Sce site within it, this posed a potentially severe limitation to the application of DSB induced gene targeting. To solve this problem, a method of creating DSBs at specific genomic sites is needed to be developed. One possible way to create such DSBs is to redesign meganucleases, such as Sce, for recognizing novel target sites [21].

Zinc finger nucleases create site specific DSBs. Type IIS restriction endonucleases are enzymes that bind a specific DNA recognition site but cleave DNA at a short distance from this site. FokI is an example of such a restriction enzyme: it binds to 5'-GGATG-3' but creates a DSB nine bp away from the binding site. Proteolysis studies of FokI showed that its DNA binding domain and its DNA cutting (nuclease) domain were separable. Chandrasegaran and his colleagues hypothesized that if they fused a new DNA binding domain to the nuclease domain they could create a restriction enzyme with a novel DNA recognition site [22]. In a series of papers they fused the nuclease domain first to a homeobox DNA binding domain and then to zinc finger DNA binding domain [23-25].

In both examples they created a protein that would cut DNA near the site of interaction with the DNA binding domain. These new proteins were initially called «chimeric nucleases», later - «zinc finger nucleases» or ZFNs. The potential of ZFNs was in the nature of the zinc finger DNA binding domain. The zinc finger DNA binding domain was first identified by Klug and colleagues and the first crystal structure was described by Pabo and colleagues [26, 27].

It has been shown that zinc finger proteins can be designed to recognize a wide variety of sequences and suggested that they can be designed to recognize nearly every sequence $[28,29]$. The initial in vitro studies of ZFNs suggested that a ZFN monomer could cut DNA but follow-up studies showed that efficient cleavage of DNA occurred when the nuclease domain is dimerized [30]. Two consequences of this required dimerization for cutting were the increasing of specificity and necessity of two ZFNs for each potential target site. 
The collaborative work of Carroll, Chandrasegaran and their colleagues showed that ZFNs could cut naked DNA in vitro and could cut DNA and stimulate a form of homologous recombination, called single-strand annealing, in Xenopus oocytes [30, 31]. The question was whether ZFNs could create DSBs in mammalian genomic DNA and thereby stimulate gene targeting.

To test this hypothesis, Porteus and Baltimore developed a green fluorescent protein (GFP) based gene targeting reporter system [32]. In this system, the GFP gene was mutated by the insertion of recognition sites for Sce and for a pair of ZFNs. This reporter was integrated as single copy in the genome of a human somatic cell line (HEK-293 cells). The reporter cell line was then transfected with a plasmid (repair template) that would correct the GFP mutation in the integrated reporter and either an expression plasmid for the Sce nuclease or expression plasmids for the ZFNs. They found that the ZFNs stimulated gene targeting as efficiently as Sce in this reporter system. Porteus and Baltimore used ZFNs for which the target binding sites were already known [32].

The next step in the development of the ZFNs was to show that ZFNs could be prospectively designed to recognize novel target sites and stimulate gene targeting at those sites $[33,34]$. Mutations in the IL2RG are the most common cause of severe combined immunodeficiency (SCID) and exon 5 is a hotspot for disease causing mutations. They found in K562 cells, a human erythroleukemia cell line, that the IL2RG ZFNs could stimulate gene targeting at one allele of the IL2RG gene in $11 \%$ of cells and both alleles of the gene in $6 \%$ of the cells. Using these ZFNs they showed that they could first mutate both alleles of the gene in a single step and then correct both alleles in a second step. Finally, they showed that the ZFNs could stimulate gene targeting up to $5 \%$ in primary human $\mathrm{T}$ cells. These results showed that DSB mediated gene targeting by ZFNs could achieve the rates that not only would be useful in an experimental setting but might also be useful as gene therapy for genetic diseases.

DNA double strand break and rAAV. rAAV and DSBs can be used to stimulate gene targeting in mammalian somatic cells. In fact, combining the two technologies seems to be synergistic $[32,35]$. While the rate of gene targeting using rAAV is about $10-100$ fold higher than using naked plasmid DNA, the rate of rAAV mediated gene targeting can be increased by a further 100 fold by inducing a DSB in the target gene.

ZFN induced gene targeting has a promising feature. But the technology is still not widely used in mammalian cells because of several unresolved issues.

Mesenchymal stem cells and induced pluripotent stem cell. Cell therapies using adult stem cells have rescued thousands of patients from induced or genetic disorders [36]. Bone marrow (BM)-derived HSC therapy was first delivered to patients in 1956, following extensive testing in a canine model [37], afterward becoming a standard clinical procedure, particularly as a treatment for leukemia and lymphoma [38]. MSCs were first described by Friedenstein and colleagues as an adherent fibroblast-like subset of the BM microenvironment called the «marrow stromal cells», which was capable of supporting hematopoiesis. Later, these fibroblast like cells were found to have adult stem cell properties as they could differentiate into cartilage, bone, fat, and tendon [36]. MSCs have been evaluated for regenerative medicine applications either through direct differentiation into these tissues or indirectly through protein or cytokine secretion and immune suppression [36, 3942]. MSCs have demonstrated systemic migration capabilities after i. v. transplantation, in particular to areas of hypoxia or tissue damage [43]. Even systemic administrations of allogeneic MSCs do not cause any adverse effects, in part due to immune modulatory effects $[44,45]$. MSCs have been considered safe as they do not show tumor formation after transplantation [46] and have been widely tested and proven efficacious in preclinical and clinical studies for cardiovascular [47] and neurodegenerative [48] diseases, graft-versus-host disease [44], and autoimmune disease.

MSCs can be efficiently transduced with retroviral and lentiviral vectors and maintain transgene expression throughout many passages and lineage-specific differentiations, with fewer complications caused by viral integrations $[49,50]$. However, the risk of tumor formation due to insertional mutagenesis by viral vector integrations still raises caution for human clinical applications [51]. Aging, moreover, significantly reduces the survival and differentiation potential of BM-MSCs [52].

Human pluripotent stem cells. hESCs have the potential to differentiate into all types of adult human 
tissues and to grow indefinitely [13]. Since their initial derivation, hESCs have become promising tools for developmental biology and regenerative medicine. However, concerns, related to ethical objections regarding the use of human embryos for hESC derivation, have dramatically restricted funding of research on these cells and, therefore, have set back the development of hESCs for clinical trials. Because of their allogeneic nature, immune rejection of cells and tissues derived from hESCs is another potential drawback to their use in transplantation. Immunosuppressive drug regimens, similar to those used for current human tissue and organ transplant procedures, might lessen the severity of the anticipated immune rejection, but at the same time, can also put the tissue recipient at an increased risk of infections. This risk can be lessened by application of human leukocyte antigen matched tissue, as is currently being practiced in organ transplantation, or could be completely eliminated by the use of the patient's own tissue. The latter possibility can now be achieved by application of autologous iPSCs, the patient's own somatic cells, and reprogramming them to become pluripotent cells [53].

Following groundbreaking work by Yamanaka and colleagues demonstrating that mouse fibroblasts could be converted into iPSCs by retroviral delivery of the genes of four transcription factors (Oct4, Sox2, Klf4, and $\mathrm{Myc}$ ), other groups reported that terminally differentiated human somatic cells could be reprogrammed into a pluripotent state using retroviral or lentiviral vectors transferring the genes of the same four transcription factors. In many ways, iPSCs are similar to hESCs, in their morphology, gene expression, in vitro differentiation potential, and teratoma formation. However, inherent «epigenetic memory» of the initial cells may influence specific differentiation and in vivo functionality of tissues derived from such reprogrammed cells. More research in this area is needed to determine the best starting somatic cell for iPSC generation that allows reproducible differentiation into different types of functional tissues for human clinical applications. iPSCs hold great potential for regenerative medicine, as can already be demonstrated in mouse models of Parkinson's disease [54] and sickle cell anemia [55]. Disease specific iPSC lines for modeling «diseases in a dish», screening new drug compounds, and developing new therapies have been used successfully [56-58]. How- ever, clinical applications of iPSCs have been criticized because of the possibility to form tumors by integrated oncogenes, c-Myc in particular [59], by insertional mutagenesis that has the potential to cause cancers [60] or disrupt tumor suppressor genes [51], and recently, because of epigenetic memories and genomic aberrations in the reprogrammed cells [61]. Therefore, to manufacture iPSCs for clinical applications, several safety measures need to be taken.

As BM-MSCs can easily be harvested from adult sources and cultured in vitro, many preclinical and clinical studies have used BM-MSCs [36]. Although easy access to BM-MSCs is recognized as a great advantage, extended in vitro culture reduces the differentiation potential of MSCs, which limits their therapeutic efficacy [62]. To overcome this shortfall, MSCs derived from iPSCs may, therefore, be considered for human cell and gene therapy applications as iPSCs have the potential to be expanded indefinitely without senescence (Figure). Several laboratories have already shown that MSCs derived from hESC have the same in vitro and in vivo characteristics as MSCs derived from adult sources $[63,64]$. It is reported that hESC derived MSCs were karyotipically stable, had the same cell surface phenotype as MSCs isolated from adult BM, and could home similarly to areas of hypoxic injury in a hindlimb ischemia model [64]. It was shown that MSCs derived from human iPSCs can be generated in clonal expansion cultures and can be differentiated into osteoblasts, adipocytes, and chondrocytes and promote vascular and muscle regeneration. The authors also described a greater regenerative potential of MSCs derived from iPSCs, which may be attributed to superior survival and engraftment after transplantation, because of higher telomerase activity and less senescence as compared to BM-MSCs [65].

In these studies, iPSC or hESC derived MSCs were comparable to BM-MSCs in surface marker expression, differentiation potential, and in vivo regenerative potential in the mouse hind limb ischemia model. Future studies should examine the efficiency of MSC derivation based on different clinically relevant protocols or cell sources, with term follow-up of in vivo safety and efficacy studies.

Genetically modified MSCs may also serve as cellular therapeutics since MSCs can be used as targeted drug 


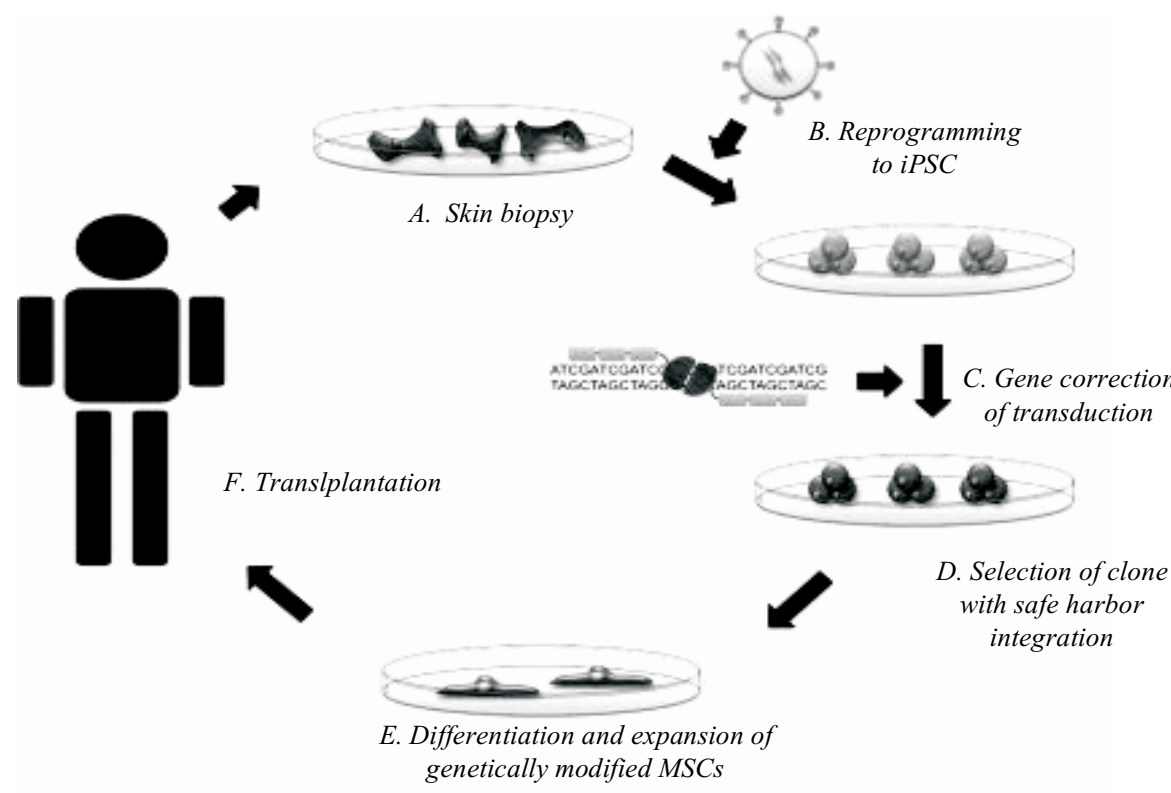

Schematic diagram of iPSC gene therapy: $A-$ patients fibroblasts from skin biopsy are cultured; $B$ - patient-specific cells can be reprogrammed by viral delivery of induction factors or nonintegrating methods; $C$-gene correction can be accomplished by vector-mediated gene transfer or gene exchange by homologous recombination; $D$ - gene-corrected iPSCs can be screened by sequencing to find a clone with proper gene correction or integration into a safe harbor site; $E$ - gene-modified iPSCs can be differentiated into MSCs and expanded; $F-$ MSCs with gene integration into the controlled site can be tested, expanded, and purified in a good manufacturing practice facility and could then be transplanted to the patient, following appropriate clearance by all regulatory agencies delivery vehicles [42]. Previous direct injection of the VEGF protein and gene therapy vectors carrying VEGF showed promise in Phase I-II clinical trials but did not achieve significance in Phase III trials [66]. MSCs, however, migrate to ischemic areas, remain there for an extended period of time, as has been demonstrated in preclinical animal models [42, 67], and could continuously deliver VEGF. This could become a cellular therapy using highly tested allogeneic, transduced MSCs. These MSCs could be generated from iPSCs that were created in an integration free system and transduced with a VEGF vector; these could be selected for safe harbor integrations of the transgene to exclude the possibility of tumor formation due to insertional mutagenesis.

Regulatory issues. The US Food and Drug Administration (FDA) regulates the clinical application of cell and gene therapy. The final cellular product administered into a patient must meet important safety and several criteria, such as identity, purity, potency, clinical safety, and efficacy [68]. Besides criteria that all cellular products must meet, such as sterility, viability and freedom from endotoxin, particular concerns for stem cells are characterization of the product, including in vitro and in vivo potency, freedom from cell differentiation to undesired cell types, in vivo cell migration/trafficking to non target site, potential uncontrolled cell proliferation or tumorigenicity, immunogenicity, graftversus-host effects, interactions with devices, other tissues or drugs in vivo. For gene-modified cells the chal- lenges are potential uncontrolled biological activity of the transgene, alteration of expression of the non-transgenes, and insertional mutagenesis.

Generation of clinically appropriate iPSCs. At this point, iPSCs are not yet clinically applicable, while being under intensive development. One of the most important goals for the manufacturing of a safe stem cell product is the prevention of tumor formation after transplantation. Tumors could be generated in iPSC mediated clinical applications by insertional mutagenesis caused by transgenes used for reprogramming [69], by enhancer effects caused by particular viral sequences found in retroviral or lentiviral vectors [60], and by disruptions of essential genes caused by integrated vector cassettes [51]. Teratomas could be caused by undifferentiated cells contaminating the differentiated final product. Integrated c-Myc delivered by a retroviral vector has been shown to cause tumor formation in $40 \%$ of mice due to the reactivation of silenced genes [69]. In adult stem cell therapies, genetically modified cells can carry the risk of tumor generation. An HSC gene therapy clinical trial to treat X-linked severe combined immunodeficiency disease (X-SCID) using a retrovirus caused 4 out of 11 children to develop leukemia $[60,70]$. Another concern may be cell transformation caused by gene disruption. An HSC therapy paper claimed that integrated lentiviral vector had disrupted a tumor suppressor gene leading to the premature termination of endogenous genes that could cause tumor formation [51]. 
This effect could be monitored by in vitro cell immortalization assays and serial transplantation experiments in vivo [46, 71].

MSCs derived from iPSCs with safe harbor therapeutic gene integrations, or gene corrections by homologous recombination, could significantly reduce the chance of tumor formation as these cells can be screened to avoid gene disruptions or oncogene activation. iPSC colonies can be specifically selected for proper gene insertion, can be highly tested, and then expanded at large scale for master cell bank generation prior to directed differentiation to MSCs or other lineages. Gene-modified iPSC derived MSCs could be used for safe administration of a therapeutic gene product to specific sites of injury or inflammation, as MSCs are known to migrate to such areas in vivo [42, 48, 64].

The improvement of reprogramming technology for safe iPSC derivation is important for human therapeutic applications, and permanent transgene integrations for reprogramming should be avoided. Recent papers have described many approaches to accomplish this, such as adenoviral vector transductions, DNA plasmid vector transfections, Cre-LoxP excision of reprogramming vector cassettes transferred by a lentiviral vector, transposons, episomal Epstein-Barr virus, mRNA transfections, and protein transfections [72]. Additionally, small molecule-mediated reprogramming has become interesting for clinically relevant iPSC generation [73].

Epigenetic memory and genetic abnormalities. Another important concern for cellular therapies is whether the transplanted cells may become unstable or could be transformed into tumors. A number of studies have demonstrated that iPSCs contain abnormalities at the genetic and epigenetic level and that these defects are often related to oncogenic pathways $[61,74-76]$. The epigenetic memory of iPSCs with its incomplete epigenetic reorganization and skewed differentiation potential also raises the question whether such cells may actually be suitable for therapeutic applications.

Cell culture conditions. Phase I clinical trial applying hESC-derived neuronal tissues for the treatment of spinal cord injury has been recently approved by the FDA. The laboratory manufacturing an iPSC or hESC derived cellular product should be in compliance with FDA safety regulations, otherwise the product will not be able to progress to Phase II or III clinical trials, and will have to be rederived. Additionally, to generate a safe and clinically acceptable iPSC-derived product, xeno-free cell culture conditions should be used to minimize the risk of transmitting disease or causing human immune reactions [68].

Reliability of iPSC differentiation. Several clinically applicable reprogramming technologies are available but still the consistency of iPSC derived products is a concern. Single cell clonal expansion of human iPSCs has shown low survival rates compared to mouse counterparts [77], therefore, developing reliable and reproducible standard protocols to differentiate and select iPSC-derived cellular products is a pressing issue.

There are indications that due to the epigenetic memory or incomplete reprogramming, some iPSC lines favor specific differentiation pathways [78]. Differentiated cells can be thought of as a heterogeneous population of desired, differentiated cells mixed with undesired, undifferentiated cells, in spite of the application of efficient direct-differentiation methods [79]. To eliminate undifferentiated PSCs from the population of differentiated cells, several techniques have to be assessed. Cell sorting using a clinical grade flow cytometric cell sorter under specific conditions can be one of the solutions. Introduction of a suicide gene only expressed in undifferentiated cells and antibodies directed against stem cell-specific surface markers could be used to selectively kill or capture and remove undifferentiated PSCs.

Conclusions. The Food and Drug Administration (FDA) has not yet approved any human gene therapy product for sale. Current gene therapy is experimental and has not proven very successful in clinical trials.

Before gene therapy can become a permanent cure for any condition, the therapeutic DNA introduced into target cells must remain functional and the cells containing the therapeutic DNA must be long-lived and stable. The problems with integrating therapeutic DNA into the genome and the rapidly dividing nature of many cells prevent gene therapy from achieving any longterm benefits. Patients will have to undergo multiple rounds of gene therapy.

The risk of stimulating the immune system in a way that reduces gene therapy effectiveness is always a potential item. Furthermore, the immune system's enhanced response to invaders it has seen before makes it dif- 
ficult for gene therapy to be repeated in patients. Viruses as the carrier of choice in most gene therapy studies pose a variety of potential problems to the patient like toxicity, immune and inflammatory responses, gene control and targeting issues. In addition, there is always the fear that the viral vector, once inside the patient, may recover its ability to cause disease.

iPSCs derived from patient's own MSCs have won the laurels for stem cell-based gene therapy. iPSCs- based therapies are under trial nowadays. It is aimed at generating stable and fully functional stem cell lines according to particular patient's need. rAAV-ZFN technology dependant homologous recombination is extensively used as gene targeting and gene correction tool. Stem cell-based therapies hold great potential to become the future regenerative medicine. Research is actively going on in this respect.

\section{3. Назір, C. Іриад}

Генна терапія, заснована на стовбурових клітинах

\section{Резюме}

Стовбурові клітини мають величезний потенціал для регенера тивної медицини. Протягом десятиліть було доведено безпеку $i$ ефективність терапії на основі HSC, у той час як використання MSC, обмежене строками зберігання клітин та деякими іншими причинами, лише в окремих експериментах давало позитивні наслідки з короткочасною дією, які потребують подальшого вивчення. Незважаючи на те, шо ІПСК залишаються основним джерелом при терапї стовбуровими клітинами, як і раніше, існують серйозні питання біобезпеки, які потрібно враховувати особливо в разі клітин, щуо продаються для клінічних випробувань. Тим не менш, найперспективнішими для регенеративної медицини майбутнього є лінії стовбурових клітин, створені для конкретного пацієнта, а також коригування гомологічних генів і вбудовування трансгена в певне місие в геномі для подальшої експресії і диференціювання. Крім того, розвиток рекомбінантної аденовірусноі технології (rAAV) і використання нуклеази иинкового пальия (ZFN) дозволяє вважати гомологічну рекомбінацію найкращим інстру ментом для генної терапії, заснованої на стовбурових клітинах.

Ключові слова: дорослі стовбурові клітини, МСК, ІПСК, ZFN, rAAV, корекиія гомологічних генів, регенеративна медиџина.

\section{3. Назир, С. Иршад}

Генная терапия, основанаая на стволовых клетках

\section{Резюме}

Стволовые клетки обладают огромным потенииалом для регенеративной медицины. На протяжении десятилетий были доказаны безопасность и эффективность терапии на основе HSC, в то время как использование MSC, ограниченное сроками хранения клеток и некоторыми другими причинами, лишь в отдельных экспериментах давало положительные результаты с кратковремен- ньм действием, что требует дальнейшего изучения. Несмотря на то, что на ИПСК возлагают большие надежды при терапии стволовыми клетками, по-прежнему существуют серьезные вопросы биобезопасности, которые нужно учитывать особенно в случае клеток, продающихся для клинических испьтаний. Тем не менее, наибольшим потенцииалом для регенеративной медицины будущего обладают линии стволовых клеток, созданные для конкретного пачиента, а также коррелячия гомологичных генов и встраивание трансгена в определенное место в геноме для дальнейтей экспрессии и дифференциачии. Кроме того, развитие рекомбинантной аденовирусной технологии (rAAV) и использования нуклеазы иинкового пальца (ZFN) позволяет считать гомологичную рекомбинацию наилучшим инструментом для генной терапии, основанной на стволовых клетках.

Ключевые слова: взрослые стволовые клетки, МСК, ИПСК, ZFN, $r A A V$, коррекиия гомологичных генов, регенеративная медииина.

\section{REFERENCES}

1. Mullen C. A., Snitzer K., Culver K. W., Morgan R. A., Anderson $W . F$. Blaese R. M. Molecular analysis of T lymphocyte-directed gene therapy for adenosine deaminase deficiency: long-term expression in vivo of genes introduced with a retroviral vector // Hum. Gene. Ther.-1996.-7, N 9.-P. 1123-1129.

2. Hacein-Bey-Abina S., Le Deist F., Carlier F., Bouneaud C., Hue C., De Villartay J. P., Thrasher A. J., Wulffraat N., Sorensen R., Dupuis-Girod S., Fischer A., Davies E. G., Kuis W., Leiva L., Cavazzana-Calvo $M$. Sustained correction of X-linked severe combined immunodeficiency by ex vivo gene therapy // N. Engl. J. Med.-2002.-346, N 16.-P. 1185-1193.

3. Hacein-Bey-Abina S., von Kalle C., Schmidt M., Le Deist F., Wulffraat N., McIntyre E., Radford I., Villeval J. L., Fraser C. C., Cavazzana-Calvo M., Fischer A. A serious adverse event after successful gene therapy for X-linked severe combined immunodeficiency // N. Engl. J. Med.-2003.-348, N 3.-P. 255-256.

4. Aiuti A., Slavin S., Aker M., Ficara F., Deola S., Mortellaro A., Morecki S., Andolfi G., Tabucchi A., Carlucci F., Marinello E., Cattaneo F., Vai S., Servida P., Miniero R., Roncarolo M. G., Bordignon $C$. Correction of ADA-SCID by stem cell gene therapy combined with nonmyeloablative conditioning // Science.2002.-296, N 5577.-P. 2410-2413.

5. Gregory C. A., Prockop D. J., Spees J. L. Non-hematopoietic bone marrow stem cells: molecular control of expansion and differentiation // Exp. Cell Res.-2005.-306, N 2.-P. 330-335.

6. Jiang Y., Jahagirdar B. N., Reinhardt R. L., Schwartz R. E., Keene C. D., Ortiz-Gonzalez X. R., Reyes M., Lenvik T., Lund T., Blackstad M., Du J., Aldrich S., Lisberg A., Low W. C., Largaespada D. A., Verfaillie C. M. Pluripotency of mesenchymal stem cells derived from adult marrow // Nature.-2002.-418, N 6893.P. 41-49.

7. Stocum D. L. Stem cells in CNS and cardiac regeneration // Adv. Biochem. Eng. Biotechnol.-2005.-93, N 1.-P. 135-159.

8. Brenner M. K., Rill D. R., Holladay M. S., Heslop H. E., Moen R. C., Buschle M., Krance R. A., Santana V. M., Anderson W. F., Ihle $J$. $N$. Gene marking to determine whether autologous marrow infusion restores long-term haemopoiesis in cancer patients // Lancet.-1993.-342, N 8880.-P. 1134-1137.

9. Reya T., Duncan A. W., Ailles L., Domen J., Scherer D. C., Willert K., Hintz L., Nusse R., Weissman I. L. A role for Wnt signalling in self-renewal of haematopoietic stem cells // Nature.-2003.423, N 6938.-P. 409-414. 
10. Willert K., Brown J. D., Danenberg E., Duncan A. W., Weissman I. L., Reya T., Yates J. R. $3^{r d}$, Nusse R. Wnt proteins are lipid-modified and can act as stem cell growth factors // Nature.-2003.423, N 6938.-P. 448-452.

11. Evans M. J., Kaufman M. H. Establishment in culture of pluripotential cells from mouse embryos // Nature.-1981.-292, N 5819.P. $154-156$

12. Martin $G$. R. Isolation of a pluripotent cell line from early mouse embryos cultured in medium conditioned by teratocarcinoma stem cells // Proc. Natl Acad. Sci. USA.-1981.-78, N 12.-P. 7634 7638 .

13. Thomson J. A., Itskovitz-Eldor J., Shapiro S. S., Waknitz M. A., Swiergiel J. J., Marshall V. S., Jones J. M. Embryonic stem cell lines derived from human blastocysts // Science.-1998.-282, N 5391.-P. 1145-1147.

14. Russell $D$. W., Hirata $R$. K. Human gene targeting by viral vectors // Nat. Genet.-1998.-18, N 4.-P. 325-330.

15. Manno C. S., Pierce G. F., Arruda V. R., Glader B., Ragni M., Rasko J. J., Ozelo M. C., Hoots K., Blatt P., Konkle B., Dake M., Kaye R., Razavi M., Zajko A., Zehnder J., Rustagi P. K., Nakai H., Chew A., Leonard D., Wright J. F., Lessard R. R., Sommer J. M., Tigges M., Sabatino D., Luk A., Jiang H., Mingozzi F., Couto L., Ertl H. C., High K. A., Kay M. A. Successful transduction of liver in hemophilia by AAV-Factor IX and limitations imposed by the host immune response // Nat. Med.-2006.-12, N 3.P. 342-347.

16. Manno C. S., Chew A. J., Hutchison S., Larson P. J., Herzog R. W., Arruda V. R., Tai S. J., Ragni M. V., Thompson A., Ozelo M., Couto L. B., Leonard D. G., Johnson F. A., McClelland A., Scallan C., Skarsgard E., Flake A. W., Kay M. A., High K. A., Glader $B$. AAV-mediated factor IX gene transfer to skeletal muscle in patients with severe hemophilia B // Blood.-2003.-101, N 8.P. 2963-2972.

17. Kohli M., Rago C., Lengauer C., Kinzler K. W., Vogelstein B. Facile methods for generating human somatic cell gene knockouts using recombinant adenoassociated viruses // Nucleic Acids Res.2004.-32, N 1.-e3.

18. Brenneman M., Gimble F. S., Wilson J. H. Stimulation of intrachromosomal homologous recombination in human cells by electroporation with site-specific endonucleases // Proc. Natl Acad. Sci. USA.-1996.-93, N 8.-P. 3608-3612.

19. Jasin M. Genetic manipulation of genomes with rare-cutting endonucleases // Trends Genet.-1996.-12, N 6.-P. 224-228.

20. Rouet P., Smih F., Jasin M. Introduction of double-strand breaks into the genome of mouse cells by expression of rarecutting endonuclease // Mol. Cell. Biol.-1994.-14, N 12.P. 8096-8106.

21. Porteus M. H., Carroll D. Gene targeting using zinc finger nucleases // Nat. Biotechnol.-2005.-23, N 8.-P. 967-973.

22. Durai S., Mani M., Kandavelou K., Wu J., Porteus M. H., Chandrasegaran $S$. Zinc finger nucleases: custom-designed molecular scissors for genome engineering of plant and mammalian cells // Nucleic Acids Res.-2005.-33, N 18.-P. 5978-5990.

23. Kim Y. G., Cha J., Chandrasegaran S. Hybrid restriction enzymes: zinc finger fusions to Fok I cleavage domain // Proc. Natl Acad. Sci. USA.-1996.-93, N 3.-P. 1156-1160.

24. Kim Y. G., Chandrasegaran S. Chimeric restriction endonuclease // Proc. Natl Acad. Sci. USA.-1994.-91, N 3.-P. 883-887.

25. Kim Y. G., Smith J., Durgesha M., Chandrasegaran S. Chimeric restriction enzyme: Gal4 fusion to FokI cleavage domain // Biol. Chem.-1998.-379, N 4.-P. 489-495.

26. Diakun G. P., Fairall L., Klug A. EXAFS study of the zinc-binding sites in the protein transcription factor IIIA // Nature.1986.-324, N 6098.-P. 698-699.
27. Pavletich N. P., Pabo C. O. Zinc finger-DNA recognition: crystal structure of a Zif268-DNA complex at 2.1 A // Science.-1991.252, N 5007.-P. 809-817.

28. Pabo C. O., Peisach E., Grant R. A. Design and selection of novel Cys2His 2 zinc finger proteins // Annu. Rev. Biochem.-2001.70.-P. 313-340.

29. Segal D. J., Barbas C. F. 3rd. Custom DNA-binding proteins come of age: polydactyl zinc-finger proteins // Curr. Opin. Biotechnol.-2001.-12, N 6.-P. 632-637.

30. Smith J., Bibikova M., Whitby F. G., Reddy A. R., Chandrasegaran $S$., Carroll $D$. Requirements for double-strand cleavage by chimeric restriction enzymes with zinc finger DNA-recognition domains // Nucleic Acids Res.-2000.-28, N 17.-P. 3361-3369.

31. Bibikova M., Carroll D., Segal D. J., Trautman J. K., Smith J., Kim Y. G., Chandrasegaran S. Stimulation of homologous recombination through targeted cleavage by chimeric nucleases // Mol. Cell. Biol.-2001.-21, N 1.-P. 289-297.

32. Porteus M. H., Cathomen T., Weitzman M. D., Baltimore D. Efficient gene targeting mediated by adeno-associated virus and DNA double-strand breaks // Mol. Cell. Biol.-2003.-23, N 10.P. 3558-3565.

33. Porteus M. H. Mammalian gene targeting with designed zinc finger nucleases // Mol. Ther.-2006.-13, N 2.-P. 438-446.

34. Urnov F. D., Miller J. C., Lee Y. L., Beausejour C. M., RockJ. M., Augustus S., Jamieson A. C., Porteus M. H., Gregory P. D., Holmes $M$. C. Highly efficient endogenous human gene correction using designed zinc-finger nucleases // Nature.-2005.-435, N 7042.-P. 646-651.

35. Miller D. G., Petek L. M., Russell D. W. Human gene targeting by adenoassociated virus vectors is enhanced by DNA doublestrand breaks // Mol. Cell. Biol.-2003.-23, N 10.-P. 35503557.

36. Parekkadan B., Milwid J. M. Mesenchymal stem cells as therapeutics // Annu. Rev. Biomed. Eng.-2010.-12.-P. 87-117.

37. Thomas E. D., Ashley C. A., Lochte H. L. Jr., Jaretzki A. 3rd, Sahler O. D., Ferrebee J. W. Homografts of bone marrow in dogs after lethal total-body radiation // Blood.-1959.-14, N 6.P. 720-736.

38. Copelan E. A. Hematopoietic stem-cell transplantation// N. Engl. J. Med.-2006.-354, N 17.-P. 1813-1826.

39. Friedenstein A. J., Chailakhyan R. K., Latsinik N. V., Panasyuk A. F., Keiliss-Borok I. V. Stromal cells responsible for transferring the microenvironment of the hemopoietic tissues. Cloning in vitro and retransplantation in vivo // Transplantation.-1974.17, N 4.-P. 331-340.

40. Ankrum J., Karp J. M. Mesenchymal stem cell therapy: Two steps forward, one step back // Trends. Mol. Med.-2010.-16, N 5.P. 203-209.

41. Karp J. M., Leng Teo G. S. Mesenchymal stem cell homing: The devil is in the details // Cell. Stem. cell.-2009.-4, N 3.-P. 206-216.

42. Meyerrose T., Olson S., Pontow S., Kalomoiris S., Jung Y., Annett G., Bauer G., Nolta J. A. Mesenchymal stem cells for the sustained in vivo delivery of bioactive factors // Adv. Drug. Deliv. Rev.-2010.-62, N 12.-P. 1167-1174.

43. Capoccia B. J., Robson D. L., Levac K. D., Maxwell D. J., Hohm S. A., Neelamkavil M. J., Bell G. I., Xenocostas A., Link D. C., Piwnica-Worms. D., Nolta J. A., Hess D. A. Revascularization of ischemic limbs after transplantation of human bone marrow cells with high aldehyde dehydrogenase activity // Blood.-2009.113, N 21.-P. 5340-5351.

44. Le Blanc K., Frassoni F., Ball L., Locatelli F., Roelofs H., Lewis I., Lanino E., Sundberg B., Bernardo M. E., Remberger M., Dini G., Egeler R. M., Bacigalupo A., Fibbe W., Ringden O. Mesenchymal stem cells for treatment of steroid-resistant, severe, acu- 
te graft-versus-host disease: a phase II study // Lancet.-2008.371, N 9624.-P. 1579-1586.

45. Aggarwal S., Pittenger M. F. Human mesenchymal stem cells modulate allogeneic immune cell responses // Blood.-2005.105, N 4.-P. 1815-1822.

46. Bauer G., Dao M. A., Case S. S., Meyerrose T., Wirthlin L., Zhou P., Wang X., Herrbrich P., Arevalo J., Csik S., Skelton D. C., Walker J., Pepper K., Kohn D. B., Nolta J. A. In vivo biosafety model to assess the risk of adverse events from retroviral and lentiviral vectors // Mol. Ther.-2008.-16, N 7.-P. 1308-1315.

47. Ripa R. S., Haack-Sorensen M., Wang Y., Jorgensen E., Mortensen S., Bindslev L., Friis T., Kastrup J. Bone marrow derived mesenchymal cell mobilization by granulocyte-colony stimulating factor after acute myocardial infarction: results from the stem cells in myocardial infarction (STEMMI) trial // Circulation.2007.-116, N 11 (suppl.).-I-24-I-30.

48. Joyce N., Annett G., Wirthlin L., Olson S., Bauer G., Nolta J. A. Mesenchymal stem cells for the treatment of neurodegenerative disease // Regen. Med.-2010.-5, N 6.-P. 933-946.

49. Brouard N., Chapel A., Thierry D., Charbord P., Peault B. Transplantation of gene-modified human bone marrow stromal cells into mouse-human bone chimeras // J. Hematother. Stem Cell. Res.-2000.-9, N 2.-P. 175-181.

50. Ding L., Lu S., Batchu R. B., Saylors R. L. III, Munshi N. C. Bone marrow stromal cells as a vehicle for gene transfer // Gene. Ther.-1999.-6, N 9.-P. 1611-1616.

51. Cavazzana-Calvo M., Payen E., Negre O., Wang G., Hehir K., Fusil F., Down J., Denaro M., Brady T., Westerman K., Cavallesco R., Gillet-Legrand B., Caccavelli L., Sgarra R., MaoucheChretien L., Bernaudin F., Girot R., Dorazio R., Mulder G. J., Polack A., Bank A., Soulier J., Larghero J., Kabbara N., Dalle B., Gourmel B., Socie G., Chretien S., Cartier N., Aubourg P., Fischer A., Cornetta K., Galacteros F., Beuzard Y., Gluckman E., Bushman F., Hacein-Bey-Abina S., Leboulch P. Transfusion independence and HMGA2 activation after gene therapy of human $\beta$-thalassaemia // Nature.-2010.-467, N 7313.-P. 318-322.

52. Roobrouck V. D., Ulloa-Montoya F., Verfaillie C. M. Self-renewal and differentiation capacity of young and aged stem cells // Exp. Cell Res.-2008.-314, N 9.-P. 1937-1944.

53. Takahashi K., Yamanaka S. Induction of pluripotent stem cells from mouse embryonic and adult fibroblast cultures by defined factors // Cell.-2006.-126, N 4.-P. 663-676.

54. Wernig M., Zhao J. P., Pruszak J., Hedlund E., Fu D., Soldner $F$., Broccoli V., Constantine-Paton M., Isacson O., Jaenisch R. Neurons derived from reprogrammed fibroblasts functionally integrate into the fetal brain and improve symptoms of rats with Parkinson's disease // Proc. Natl Acad. Sci. USA.-2008.-105, N 15.-P. 5856-5861.

55. Hanna J., Wernig M., Markoulaki S., Sun C. W., Meissner A., Cassady J. P., Beard C., Brambrink T., Wu L. C., Townes T. M., Jaenisch $R$. Treatment of sickle cell anemia mouse model with iPS cells generated from autologous skin // Science.-2007.318, N 5858.-P. 1920-1923.

56. Ebert A. D., Yu J., Rose F. F., Mattis V. B., Lorson C. L., Thomson J. A., Svendsen C. N. Induced pluripotent stem cells from a spinal muscular atrophy patient // Nature.-2009.-457, N 7227.P. 277-280.

57. Park I. H., Arora N., Huo H., Maherali N., Ahfeldt T., Shimamura A., Lensch M. W., Cowan C., Hochedlinger K., Daley G. Q. Disease-specific induced pluripotent stem cells // Cell.-2008.134, N 5.-P. 877-886.

58. Kambal A., Mitchell G., Cary W., Gruenloh W., Jung Y., Kalomoiris S., Nacey C., McGee J., Lindsey M., Fury B., Bauer G., Nolta J. A., Anderson J. S. Generation of HIV-1 resistant and functional macrophages from hematopoietic stem cell-derived induced pluripotent stem cells // Mol. Ther.-2011.-19, N 3.P. 584-593.

59. Okita K., Ichisaka T., Yamanaka S. Generation of germline-competent induced pluripotent stem cells // Nature.-2007.-448, N 7151.-P. 313-317.

60. Hacein-Bey-Abina. S., Von Kalle C., Schmidt M., McCormack M. P., Wulffraat N., Leboulch P., Lim A., Osborne C. S., Pawliuk R., Morillon E., Sorensen R., Forster A., Fraser P., Cohen J. I., de Saint Basile G., Alexander I., Wintergerst U., Frebourg T., Aurias A., Stoppa-Lyonnet D., Romana S., Radford-Weiss I., Gross F., Valensi F., Delabesse E., Macintyre E., Sigaux F., Soulier J., Leiva L. E., Wissler M., Prinz C., Rabbitts T. H., Le Deist F., Fischer A., Cavazzana-Calvo M. LMO2-associated clonal $\mathrm{T}$ cell proliferation in two patients after gene therapy for SCID-X1 // Science.-2003.-302, N 5644.-P. 415-419.

61. Gore A., Li Z., Fung H. L., Young J. E., Agarwal S., Antosiewicz-Bourget J., Canto I., Giorgetti A., Israel M. A., Kiskinis E., Lee J. H., Loh Y. H., Manos P. D., Montserrat N., Panopoulos A. D., Ruiz S., Wilbert M. L., Yu J., Kirkness E. F., Izpisua Belmonte J. C., Rossi D. J., Thomson J. A., Eggan K., Daley G. Q., Goldstein L. S., Zhang $K$. Somatic coding mutations in human induced pluripotent stem cells // Nature.-2011.-471, N 7336.-P. 63-67.

62. Katsara O., Mahaira L. G., Iliopoulou E. G., Moustaki A., Antsaklis A., Loutradis D., Stefanidis K., Baxevanis C. N., Papamichail M., Perez S. A. Effects of donor age, gender, and in vitro cellular aging on the phenotypic, functional, and molecular characteristics of mouse bone marrow-derived mesenchymal stem cells // Stem Cells Dev.-2011.-20, N 9.-P. 1549-1561.

63. Hematti $P$. Human embryonic stem cell-derived mesenchymal progenitors: an overview // Methods Mol. Biol.-2011.-690.P. 163-174.

64. Gruenloh W., Kambal A., Sondergaard C., McGee J., Nacey C., Kalomoiris S., Pepper K., Olson S., Fierro F., Nolta J. A. Characterization and in vivo testing of mesenchymal stem cells derived from human embryonic stem cells // Tissue. Eng. Part. A.2011.-17, N 11-12.-P. 1517-1525.

65. Lian Q., Zhang Y., Zhang J., Zhang H. K., Wu X., Zhang Y., Lam F. F., Kang S., Xia J. C., Lai W. H., Au K. W., Chow Y. Y., Siu C.W., Lee C. N., Tse H. F. Functional mesenchymal stem cells derived from human induced pluripotent stem cells attenuate limb ischemia in mice // Circulation.-2010.-121, N 9.-P. 11131123.

66. Fierro F., Kalomoiris S., Sondergaard C., Nolta J. A. Effects on proliferation and differentiation of multipotent bone marrow stromal cells engineered to express growth factors for combined cell and gene therapy // Stem Cells.-2011.-29, N 11.-P. 17271737.

67. Meyerrose T. E., Roberts M., Ohlemiller K. K., Vogler C. A., Wirthlin L., Nolta J. A., Sands M. S. Lentiviral-transduced human mesenchymal stem cells persistently express therapeutic levels of enzyme in a xenotransplantation model of human disease // Stem Cells.-2008.-26, N 7.-P. 1713-1722.

68. Halme D. G., Kessler D. A. FDA regulation of stem-cell-based therapies // N. Engl. J. Med.-2006.-355, N 16.-P. 1730-1735.

69. Nakagawa M., Koyanagi M., Tanabe K., Takahashi K., Ichisaka T., Aoi T., Okita K., Mochiduki Y., Takizawa N., Yamanaka S. Generation of induced pluripotent stem cells without Myc from mouse and human fibroblasts // Nat. Biotechnol.-2008.-26, N 1.P. 101-106.

70. Hacein-Bey-Abina S., Garrigue A., Wang G. P., Soulier J., Lim A., Morillon E., Clappier E., Caccavelli L., Delabesse E., Beldjord K., Asnafi V., MacIntyre E., Dal Cortivo L., Radford I., Brousse N., Sigaux F., Moshous D., Hauer J., Borkhardt A., Be- 
lohradsky B. H., Wintergerst U., Velez M. C., Leiva L., Sorensen R., Wulffraat N., Blanche S., Bushman F. D., Fischer A., Cavazzana-Calvo $M$. Insertional oncogenesis in 4 patients after retrovirus-mediated gene therapy of SCID-X1 // J. Clin. Invest.2008.-118, N 9.-P. 3132-3142.

71. Montini E., Cesana D., Schmidt M., Sanvito F., Ponzoni M., Bartholomae C., Sergi Sergi L., Benedicenti F., Ambrosi A., Di Serio $C$., Doglioni $C$., von Kalle $C$., Naldini $L$. Hematopoietic stem cell gene transfer in a tumor-prone mouse model uncovers low genotoxicity of lentiviral vector integration // Nat. Biotechnol.2006.-24, N 6.-P. 687-696.

72. Gonzalez F., Boue S., Izpisua Belmonte J. C. Methods for making induced pluripotent stem cells: reprogramming a la carte // Nat. Rev. Genet.-2011.-12, N 4.-P. 231-242.

73. Zhu S., Li W., Zhou H., Wei W., Ambasudhan R., Lin T., Kim J., Zhang K., Ding $S$. Reprogramming of human primary somatic cells by OCT4 and chemical compounds // Cell. Stem Cell.-2010.-7, N 6.-P. 651-655.

74. Hussein S. M., Batada N. N., Vuoristo S., Ching R. W., Autio R., Narva E., Ng S., Sourour M., Hamalainen R., Olsson C., Lundin K., Mikkola M.,Trokovic R., Peitz M., Brustle O., Bazett-Jones D. P., Alitalo K., Lahesmaa R., Nagy A., Otonkoski T. Copy number variation and selection during reprogramming to pluripotency // Nature.-2011.-471, N 7336.-P. 58-62.

75. Lister R., Pelizzola M., Kida Y. S., Hawkins R. D., Nery J. R., Hon G., Antosiewicz-Bourget J., O'Malley R., Castanon R., Klugman
S., Downes M., Yu R., Stewart R., Ren B., Thomson J. A., Evans $R$. M., Ecker J. R. Hotspots of aberrant epigenomic reprogramming in human induced pluripotent stem cells // Nature.-2011.471, N 7336.-P. 68-73.

76. Mayshar Y., Ben-David U., Lavon N., Biancotti J. C., Yakir B. Clark A. T., Plath K., Lowry W. E., Benvenisty N. Identification and classification of chromosomal aberrations in human induced pluripotent stem cells // Cell. Stem. Cell.-2010.-7, N 4.P. 521-531.

77. Hanna J. H., Saha K., Jaenisch R. Pluripotency and cellular reprogramming: facts, hypotheses, unresolved issues // Cell.-2010.143, N 4.-P. 508-525.

78. Kim K., Doi A., Wen B., Ng K., Zhao R., Cahan P., Kim J., Aryee M. J., Ji H., Ehrlich L. I., Yabuuchi A., Takeuchi A., Cunniff K. C., Hongguang H., McKinney-Freeman S., Naveiras O., Yoon T. J., Irizarry R. A., Jung N., Seita J., Hanna J., Murakami P., Jaenisch R., Weissleder R., Orkin S. H., Weissman I. L., Feinberg A. $P$., Daley G. $Q$. Epigenetic memory in induced pluripotent stem cells // Nature.-2010.-467, N 7313.-P. 285-290.

79. Cohen D. E., Melton D. Turning straw into gold: directing cell fate for regenerative medicine // Nat. Rev. Genet.-2011.-12, N 4.-P. 243-252.

Received 30.07.12 